\title{
Electric field theory and the fallacy of void capacitance
}

\author{
McAllister, lain Wilson
}

Published in:

IEEE Transactions on Electrical Insulation

Link to article, DOI:

10.1109/14.85117

Publication date:

1991

Document Version

Publisher's PDF, also known as Version of record

Link back to DTU Orbit

Citation (APA):

McAllister, I. W. (1991). Electric field theory and the fallacy of void capacitance. IEEE Transactions on Electrical Insulation, 26(3), 458-459. https://doi.org/10.1109/14.85117

\section{General rights}

Copyright and moral rights for the publications made accessible in the public portal are retained by the authors and/or other copyright owners and it is a condition of accessing publications that users recognise and abide by the legal requirements associated with these rights.

- Users may download and print one copy of any publication from the public portal for the purpose of private study or research.

- You may not further distribute the material or use it for any profit-making activity or commercial gain

- You may freely distribute the URL identifying the publication in the public portal

If you believe that this document breaches copyright please contact us providing details, and we will remove access to the work immediately and investigate your claim. 
PARTIAL DISCHARGES

\title{
Electric Field Theory and the Fallacy of Void Capacitance
}

\author{
I. W. McAllister \\ Physics Laboratory II, \\ The Technical University of Denmark, Lyngby, \\ Denmark
}

$\mathrm{T}$ HE problems associated with electrical insulation arise 1 essentially from the stressing of the insulating media, be these solid liquid or gas, by the application of an electric field. Consequently a knowledge of electric fields is of paramount importance in obtaining an appreciation of the science of electrical insulation. The ready acquisition of a sufficient depth of knowledge is however difficult as nearly all the appropriate textbooks are out of print. This condition is compounded by the fact that, as the subject of continuum electromagnetism had reached maturity already in the second half of the 19 th century, much valuable literature from this period has suffered neglect through the passage of time. Furthermore, it should be emphasized that, although experimental data and incomplete physical theories are invariably superseded with the passage of time, this situation does not arise with the mathematics of electromagnetism.

The majority of textbooks currently in print attempt to cover the entire subject of electromagnetism in a single volume. Inevitably this leads to only two or three chapters on electrostatic and conduction fields, and hence the subject cannot be treated to a level sufficient to address the complex situations which arise in electrical insulation. In addition, this lack of depth in approach invariably lends itself to a trivialization of electric field theory, such that conceptual misunderstandings develop with the risk of becoming incorporated in specialized literature. A classic example of this trend is the concept of the capacitance of a gaseous void [1-4]. As the acceptance of this capacitance is so embedded in the world of partial discharge studies, an attempt to dispel it follows.

For a Laplacian field, the capacitance $C$ between two conductors is defined by the ratio

$$
C \equiv \frac{|Q|}{U}
$$

where $U$ is the potential difference between the two conductors and $|Q|$ is the magnitude of the charge carried by each conductor associated with this particular potential difference. For $U$ to exist, the actual charges distributed on the conductor surfaces must be of opposite polarity. (If $|Q|$ is not the total charge on each of the conductors, then $C$ represents the partial capacitance between the said conductors). Moreover, the definition of capacitance is valid only for a Laplacian field, for which $|Q|$ is directly proportional to $U$. This proportionality does not exist in a Poissonian field, i.e., when space charge exists in the volume between the electrodes.

In the context of the present discussion however, the most pertinent aspect of the capacitance definition is that of reference to a single-valued potential difference between surfaces. This implies that these surfaces must be surfaces of equipotential. With this essential characteristic in mind the validity of 'void capacitance' can now be examined.

Consider the case of a spherical void of radius $R$ in an extended uniform field $E_{0}$ which is oriented in the negative $z$ direction. From an analysis of the electrostatic field, see for example Section 3.3 of [5], it can be shown that the potential $\phi_{w}$ of the void wall is given by

$$
\phi_{w}=\frac{3 \varepsilon_{r}}{2 \varepsilon_{r}+1} R E_{0} \cos \theta
$$

where $\varepsilon_{r}$ is the relative permittivity of the bulk material and $\theta$ the spherical polar coordinate.

From (2) it is evident that the void wall $(0 \leqslant \theta<\pi)$ is not an equipotential surface, and thus to ascribe a capacitance to a void violates the basic definition of capacitance. Quite simply void capacitance does not exist. Moreover, for a perfect dielectric, no charges are present on the wall prior to discharge activity. This condition again substantiates that the application of (1) to the void problem is meaningless.

The fact that, for $\theta<\pi / 2, \phi_{w}$ is positive while $\phi_{w}$ is negative for $\theta>\pi / 2$, arises because, in the extended

0018-9367/91/0600-458\$1.00 (C) 1991 IEEE 
uniform field, the potential of the equatorial plane of the void is set to zero. In practice the void location in the applied field will be associated with a non-zero potential, and hence $\phi_{w}$ will represent a perturbation on this potential value.

The usual method of characterizing the electrical properties of insulated (zero net charge) dielectric bodies is to refer to their multipole moments, and of these the dipole moment is the most important. This approach was adopted by Pedersen [6-8] to develop a theory of partial discharge transients, in which he introduced the dipole moment associated with the charge deposited on the void wall following an internal discharge. As a void is a closed volume, this additional component of the void dipole moment is still associated with zero net charge. With reference to partial discharge detection, it is this change in void dipole moment which is of importance, as this gives rise to the electrical transient observed across the system terminals.

Furthermore, the dipole representation of a partial discharge in a bulk void suggests an elegant means of examining the partial discharge influence upon neighboring voids. From the above discussion, it is evident that an equivalent circuit approach involving fictitious partial capacitances would be completely meaningless.

In conclusion, equivalent circuits may be used to simulate PD transients as an aid in the development of detection equipment. But field problems of the above nature should be addressed through the application of field theory.

\section{REFERENCES}

[1] S. Whitehead, Dielectric Breakdown in Solids, Clarendon Press Oxford 1951.

[2] F. H. Kreuger, Discharge Detection in High Voltage Equipment, Temple Press Books London 1964.

[3] R. Bartnikas and E. J. McMahon (eds.), Engineering Dielectrics - Volume I. Corona Measurement and Interpretation, ASTM Special Technical Publication STP 669. ASTM Philadelphia 1979.

[4] F. H. Kreuger, Partial Discharge Detection in HighVoltage Equipment, Butterworths London 1989.

[5] I. W. McAllister and G. C. Crichton, "Analysis of the Temporal Electric Fields in Lossy Dielectric Media", IEEE Trans. Elect. Insul, Vol. 26, this issue, 1991.

[6] A. Pedersen, "Partial Discharges in Voids in Solid Dielectrics. An Alternative Approach", 1987 Annual Report - Conference on Electrical Insulation and Dielectric Phenomena, 1987. IEEE Publication 87CH 2462-0, pp. 58-64, 1987.

[7] G. C. Crichton, P. W. Karlsson and A. Pedersen, "Partial Discharges in Ellipsoidal and Spheroidal Voids", IEEE Trans. Elect. Insul., Vol. 24, pp. 335-342, 1989.

[8] A. Pedersen, "On the Electrodynamics of Partial Discharges in Voids in Solid Dielectrics", Proceedings 3rd International Conference on Conduction and Breakdown in Solid Dielectrics, Trondheim 1989. IEEE Publication 89CH2726-8, pp. 107-116, 1989.

Manuscript was received on 15 March 1991 